\title{
Shaping the Medical Market: On the Construction of Quackery and Folk Medicine in Dutch Historiography
}

\author{
FRANK HUISMAN*
}

It has been stated many times: traditionally, medical history was written by, for and about doctors, telling the story of unilinear scientific progress. Positivism tended to look at the history of medicine as a process of linear progress from religion through metaphysics to science, in which mankind was liberated from superstition and irrationality. This view was confirmed by the Weberian notion of a "disenchantment" of the world: in the course of the last few centuries, the influence of magic and animism was seen as having declined. In the field of medical thinking and medical practice, man was thought to have freed himself from the chains of superstition. Gradually, he had learned to relate to the world in rational terms; in the event of illness, academic doctors were the logical engineers of his body. However, the times of the grand stories are over, in general as well as in medical history. With non-physicians moving into the field, there has been a growing awareness of the constructed nature of medicine. ${ }^{1}$ Medical knowledge has come to be seen as functioning within a specific cultural context from which it derives its meaning. ${ }^{2}$ Today, illness is no longer considered to be a universal, ontological unit. Instead, the meaning of illness-as well as the response to it-is thought to be determined by factors of a social, economic, political and religious nature. ${ }^{3}$

The attraction of the old historical image lay in its simplicity. However, it is highly problematic to characterize developments in the field of health care in terms of a

\section{* Frank Huisman, PhD, University of Maastricht, Department of History, PO Box 616, 6200 MD Maastricht, The Netherlands.}

This research was supported by the Foundation for History, Archaeology and Art History (SHW), which is subsidized by the Netherlands Organization for Scientific Research (NWO).

${ }^{1}$ See, for example, Peter Wright and Andrew Treacher (eds), The problem of medical knowledge: examining the social construction of medicine, Edinburgh University Press, 1982; Jens Lachmund and Gunnar Stollberg (eds), The social construction of illness: illness and medical knowledge in past and present, Stuttgart, F Steiner, 1992; Charles E Rosenberg and Janet Golden (eds), Framing disease: studies in cultural history, New Brunswick, Rutgers University Press, 1991; Ludmilla Jordanova, 'The social construction of medical knowledge', Soc. Hist. Med., 1995, 8: 361-81.

\footnotetext{
2 On the relationship between medical ideas and social context, see the subtle argument in Charles Rosenberg, 'Woods or trees? Ideas and actors in the history of science', Isis, 1988, 79: 564-70; idem, Explaining epidemics and other studies in the history of medicine, Cambridge University Press, 1992, esp. pp. 1-6, and in John Harley Warner, 'Science in medicine', Osiris 1985, 1: 37-58; idem, 'The history of science and the sciences of medicine', Osiris, 1995, 10: 164-93.

${ }^{3}$ In this respect, medical history owes much to medical anthropology. See, for example, Arthur Kleinman, Patients and healers in the context of culture: an exploration of the borderland between anthropology, medicine and psychiatry, Berkeley, University of California Press, 1980; Sjaak van der Geest and Gerard Nijhof (eds), Ziekte, gezondheidszorg en cultuur. Verkenningen in de medische antropologie en sociologie, Amsterdam, Het Spinhuis, 1989.
} 
disenchantment. It would imply the virtual disappearance of non-orthodox healing in the twentieth century, whereas the opposite proves to be the case. ${ }^{4}$ In 1993 , at the request of the Ministry of Health, the Dutch Health Council published a report on the nature and position of alternative medicine in the Netherlands. It showed that alternative ways of healing are still very important today, both in terms of the number of patient-healer contacts and in the money involved. At the end of the twentieth century, faith-healing, homoeopathy, pilgrimages, acupuncture and anthroposophy - to name but a few - are still important healing options. ${ }^{5}$ This need not surprise us when we look at the conceptual side of the matter. The suggestion that went with positivism and disenchantment theories was that "rationality" is an unproblematic concept that coincides with science. However, as the social history of medicine has made clear, science is but one form of rationality. If a belief is rational when it is considered coherent by those who hold it, magical behaviour can be highly rational. In other words, what is considered rational in one context can be rejected as being non-rational in another. ${ }^{6}$ Since people in the late twentieth century keep on trying to make sense of illness and suffering in a "non-rational" way, the conclusion should be that the enchantment continues.

The implications of the constructivist perspective in medical history are far-reaching. Gone are the days of nice, well-organized narratives of the struggle of mankind to wrench the secrets out of nature in order to end suffering and illness. Gone too are the times when relationships within the realm of health care seemed clear: on the one hand, academic medicine-rational, modest and humanitarian - on the other, humbug and wilful deceit. Scientific heroes have fallen from their pedestals; they have been reduced to common mortals, who produced certain benefits for society. ${ }^{7}$ Meaning in the field of illness and healing is no longer considered to be the monopoly of orthodox medicine. Instead, it is seen as arbitrary and contingent and dependent on contextual factors. In order to find out how patient behaviour is conditioned, each particular context will have to be examined. This pulverizing of the traditional historical image has often been deplored. However, by analysing the construction of quackery and folk medicine in Dutch historiography, I hope to make clear that the discipline has only gained from its renewal. ${ }^{8}$

The social history of medicine likes to describe health care systems in terms of a medical market. ${ }^{9}$ It is an attractive heuristic perspective, since it is much more dynamic

\footnotetext{
${ }^{4}$ See, for example, Willem de Blécourt, 'On the continuation of witchcraft', in Jonathan Barry, Marianne Hester and Gareth Roberts (eds), Witchcraft in early modern Europe: studies in culture and belief, Cambridge University Press, 1996, pp. 335-52; Marijke Gijswijt-Hofstra, Vragen bij een onttoverde wereld, Amsterdam, Historisch Seminarium Universiteit van Amsterdam, 1997.

5 Alternatieve behandelwijzen en wetenschappelijk onderzoek, The Hague, Gezondheidsraad, 1993. See also, Gerrit van Vegchel, Medici contra kwakzalvers. De strijd tegen niet-orthodoxe geneeswijzen in Nederland in de $19 e$ en 20e eeuw, Amsterdam, Het Spinhuis, 1991, esp. ch. 4.

${ }^{6}$ For the different "cultural repertoires" in Western Europe with regard to illness and healing,
}

see the articles contained in Marijke GijswijtHofstra, Hilary Marland and Hans de Waardt (eds), Illness and healing alternatives in Western Europe, London, Routledge, 1997.

${ }^{7}$ For an overview of the historiographical images of well-known "heroes of science" like Galilei, Newton, Pasteur and others, see Bert Theunissen, Casper Hakfoort, et al., Newtons God en Mendels bastaarden. Nieuwe visies op de 'Helden van de wetenschap', Amsterdam, Meulenhoff, 1997.

${ }^{8}$ See also Frank Huisman, 'Medische encyclopedie en sociaal-constructivisme. Twee hoofdstromen in de medische historiografie', Groniek, 1995, 29: 132-55.

${ }^{9}$ Matthew Ramsey, Professional and popular medicine in France, 1770-1830: the social world of medical practice, Cambridge University Press, 1988; 


\section{Quackery and Folk Medicine in Dutch Historiography}

than the traditional one. From the point of view of the patient-the demand side-the medical market can be considered as the spectrum of healing options, ranging from selfhelp to consulting a professional healer. From that of the healer-the supply side - the concept focuses on specialization, popularity and competition. However, although the concept has introduced economics into the field of health care, its cultural dimension may be even more important:

The medical market was the arena where the effectiveness and success of a bid for trust and of the language that was used to ask for trust, were put to the test. Whether a cultural repertoire of illness was accepted by other people could only be established at this meeting point between healers, patients and other interested parties. ${ }^{10}$

In the medical market different knowledge claims and healing practices struggled for recognition. Consultation behaviour was highly dependent on trust, belief and esteem on behalf of the patient. How was demand for medical advice created? And, once created, how was it canalized? If health care is a battlefield where the favour of the patient is the bounty, ${ }^{11}$ it is crucial to have an understanding of the mechanisms of in- and exclusion. Or, to put it differently: what constituted good medical treatment and who was to decide?

In a slightly different context, it has been remarked that the task of the historian is not so much to trace the accumulation of scientific knowledge as to understand the organization of knowledge. ${ }^{12}$ This article charts the attempts to locate quackery and folk medicine-thereby organizing knowledge and shaping the medical market-in Dutch historiography. Since there are no self-evident or universal boundaries separating science from magic and superstition-or, for that matter, orthodox medicine from quackery and folk medicine-it is not about "real" quacks but about constructed or conceived ones. Physicians have always felt the need to draw a demarcation line between their own discipline and non-medicine. This not only implied the creation of a professional selfimage, but an image of the "medical other" as well. ${ }^{13}$ However, although there have been many attempts to disqualify alternative conceptions of illness and healing as irrational and irrelevant, it will become clear that physician-medical historians never formed a monolithic group of quack-bashers. Positivists are often said to look at folk medicine and quackery as a residue of a magical, superstitious past on the verge of disappearing. They have been depicted as Whiggish, one-dimensional and historically naive. This, as I will try to make clear, is a caricature made by a young discipline-the social history of medicine-that wanted a place under the sun. The older medical historians each put history to a different use, depending on their position in time and society. Accordingly, folk medicine and quackery played a different role in their historical narrative.

Ann Digby, Making a medical living: doctors and patients in the English market for medicine, 1720-1911, Cambridge University Press, 1994; Gerrit van Vegchel, 'De medische markt en de historiografische herorintatie in de medische geschiedschrijving', in Willem de Blécourt and Gerrit van Vegchel (eds), De medische markt. Special edition of Focaal. Tijdschrift voor antropologie, 1993, 21: pp. 9-42; Willem de Blécourt, Frank Huisman and Henk van der Velden, 'De medische markt in Nederland 1850-1950', in idem (eds), Special edition of Tijdschrift voor sociale geschiedenis

(forthcoming).

${ }^{10} \mathrm{Gijswijt-Hofstra,} \mathrm{et} \mathrm{al.,} \mathrm{op.} \mathrm{cit.,} \mathrm{note} 6$ above, p. 11 .

11 Van der Geest and Nijhof, op. cit., note 3 above, pp. 4-5.

12 Warner, op. cit., note 2 above, p. 166.

13 A K Lingo, 'Empirics and charlatans in early modern France: The genesis of the classification of the "other" in medical practice', J. soc. Hist., 1985/86, 19: 583-603. 


\section{Frank Huisman}

With regard to the style and contents of medical historiography written by physicians, I would like to propose a typology of three. First, there was the learned physician, who was well-versed in Greek and Latin and who still thought very much along the philological lines of medical humanism. Representatives of this type were rooted in the so-called pragmatic tradition, whose "founding father" was Kurt Sprengel. They used medical history as a didactic instrument in universities. Second, there was the bridgebuilding physician, who was aware of the major epistemological transformation medicine had gone through in the course of the nineteenth century. He was eager to bridge the gap between the two cultures (science and the humanities) and between the doctor and the patient that had resulted from it. The most important representative of this type was Theodor Puschmann. Third, there was the scientist-physician and educator of the people, who was proud of the achievements of medical science and demanded a social position for physicians that would match these developments. He wanted to persuade lay-people of the extraordinary value of academic medicine, denouncing all heterodoxy. What united all three was their evolutionary perspective on the history of medicine, with outspoken positivist traits.

\section{The History of Medical Ideas in the Academic Curriculum}

Medical history as an autonomous discipline has its roots in the early nineteenth century with the German professor of medicine Kurt Sprengel (1766-1833) as its founding father. ${ }^{14}$ With his five-volume Versuch einer pragmatische Geschichte der Arzneykunde, which appeared from 1792 onwards, he made medical history explicitly subservient to medical education. Medicine was considered to be an integral part of general culture that was held to be one and indivisible. Progress in medicine, thought to be inescapable, reflected general historical developments. Therefore, medical history should not describe the endless multiformity of medical ideas in the past, but should rather make an effort to find and understand the historical patterns that lay behind them. Starting from the assumption that one can learn from the past, Sprengel and his followers, like Isensee and Haeser, primarily attributed an educational function to medical history. In the medical curriculum, they wanted to offer the history of civilization condensed in the history of medicine. This would not only make the student a better physician, but a valuable and right-minded member of society as well. Because the student could profit from the discoveries and mistakes of his predecessors, he would have a head start from which humanity as a whole would profit.

Levi Ali Cohen (1817-1889) and Abraham Hartog Israëls (1822-1883) were the most important Dutch representatives of this so-called pragmatic tradition. Ali Cohen was one of the founders of both the Dutch Society for the Advancement of Medicine (NMG) and the Dutch Journal of Medicine (NTvG). ${ }^{15} \mathrm{He}$ was active in the fields of public hygiene,

14 Charles Webster, 'The historiography of medicine', in Pietro Corsi and Paul Weindling (eds), Information sources in the history of science and medicine, London, Butterworth Scientific, 1983, pp. 29-43.

15 On Ali Cohen, see C E Daniëls, 'In memoriam', Nederlandsch tijdschrift voor geneeskunde, 1889, 25
(2): 696-8; G A Lindeboom, Dutch medical biography: a biographical dictionary of Dutch physicians and surgeons 1475-1975, Amsterdam, Rodopi, 1984, pp. 357-8. Eddy Houwaart is preparing a biography on Ali Cohen. For the moment, see his 'Gronings romanticus en nationaal hervormer: de hygiënist Levy Ali Cohen 


\section{Quackery and Folk Medicine in Dutch Historiography}

medical statistics and medical history, and he was involved in the revision of the Dutch Health Act (passed in 1865). Because of his strong commitment to the sanitary movement he was appointed medical inspector of the northern provinces in the same year. Israëls too was involved in the foundation of the NMG and of several medical journals. ${ }^{16} \mathrm{His}$ publications dealt with medical history, medical geography, medical police and epidemiology, as well as combinations of these fields. He was also involved in the sanitary movement. Israëls became a member of the Amsterdam Health Committee, the Medical Council and the Cholera Committee; in 1877, he was appointed professor in the history of medicine and hygiene in Amsterdam (after having been lector of hygiene, the encyclopaedia and the history of medicine from 1867 onwards). According to both Ali Cohen and Israëls, medical history could make an important contribution to medicine and health care. They saw a close connection between hygiene and medical history. Because they thought knowledge of the medical past was indispensable for every physician, they translated and edited the handbooks of two German medical historians whose views they wholeheartedly embraced. Ali Cohen translated Die Geschichte der Medicin und ihrer Hülfswissenschaften by Emil Isensee, while Israëls did the same with Lehrbuch der Geschichte der Medicin und der Volkskrankheiten, written by Heinrich Haeser. ${ }^{17}$

In their composition and theoretical outlook, both books breathe the spirit of Kurt Sprengel, and both are characterized by the Hegelian conception of history, the Humboldtian teaching ideal and the pragmatic goal that is considered typical of the genre. ${ }^{18}$ In his foreword, Israëls defined the task of historiography as striving for "the understanding of developments, of the new, of the present". For the German authors, as well as for their Dutch translators, historical periodization had an absolute value. Isensee divided history into a Greek, a Roman, an Arabic-scholastic and a Germanic age. Each of these periods was considered to be a temporary embodiment of the Hegelian Worldspirit (Weltgeist). Haeser, without explicitly mentioning Comte (or Spencer), organized his material along positivist lines. He distinguished a theurgic, an artificial, a dialectical, and a scientific age, referring to the pre-Hippocratic era, classical Antiquity, the Middle Ages, and the period from the sixteenth century onwards. According to both Isensee and Haeser-and their translators agreed with them-the triumph of truth, freedom and humanity started in the Renaissance, when classical speculative reasoning was overcome by modern science.

\footnotetext{
(1817-1889)', in Frank Huisman and Catrien Santing (eds), Medische geschiedenis in regionaal perspectief: Groningen 1500-1900, Rotterdam, Erasmus Publishing, 1997, pp. 101-30. On the Dutch sanitary movement, see E S Houwaart, De hygiënisten. Artsen, staat \& volksgezondheid in Nederland 1840-1890, Groningen, Historische Uitgeverij, 1991.

16 On Israëls, see Gedenkboek van het Athenaeum en de Universiteit van Amsterdam 1632-1932, Amsterdam, Stadsdrukkerij, 1932, pp. 199-203 and 606-7; C E Daniëls, 'Levensschets van dr A.H. Israëls', Nederlandsch tijdschrift voor geneeskunde, 1884, 20 (2): pp. 881-903 and 913-27 (incl.
}

bibliography); Lindeboom, op. cit., note 15 above, pp. 957-9. Israëls was editor of Geneeskundige courant, Nederlandsch weekblad voor geneeskundigen, Nederlandsch tijdschrift voor geneeskunde and Hygieia. Weekblad voor de gezondheidsleer in Nederland.

${ }_{17}$ E Isensee, Oude en middel-geschiedenis van de geneeskunde en hare hulpwetenschappen, translated and edited by L Ali Cohen, Groningen, Van Zweeden, 1847; H Haeser, Leerboek van de geschiedenis der geneeskunde, translated and edited after the second edition by A H Israëls, Utrecht, $\mathrm{C}$ van der Post, 1859.

18 Webster, op. cit., note 14 above. 


\section{Frank Huisman}

Because Ali Cohen and Israëls-like Isensee and Haeser-dealt with medical teaching at university level and not with medical practice, folk medicine and quackery were not issues in their historiography. Although Ali Cohen, being a health inspector, came into contact with quackery quite often, ${ }^{19}$ in his publications it seems to have been a non-issue for him. In his Handboek der openbare gezondheidsregeling en der geneeskundige politie (Handbook on public health care), for example, he discussed foodstuffs, housing, occupational medicine, epidemiology, and medical inspection, but not quackery. ${ }^{20}$ Being fully preoccupied with the building of a new system of medical education, the work of Ali Cohen and Israëls primarily shows how a new, scientific self-image of the profession was being created and how the pioneers of the profession believed medical knowledge should be organized. In short, they were far from the cliché of quack-bashers that the social history of medicine has made of all nineteenth-century physician-medical historians. In the 1920s and 1930s, Jan Gerard de Lint (1867-1936) worked in a similar vein. In 1924, he became a private lecturer in the history of medicine at Leiden University. In 1933, he published a Dutch translation of Sigerist's Einführung in die Medizin. ${ }^{21}$ Like the handbooks mentioned above, it was aimed at teaching the principles of medicine as a science, drawing examples from the past.

\section{The History of Folk Medicine and Communicating Illness}

After the transformation of medicine in the nineteenth century, a split in medical historiography occurred: one branch sought to reconcile the differences that resulted from the "scientification" of medicine, while the other emphasized them. When Israëls died in 1883, no successor was appointed to the chair of medical history. Due to the transformation in medicine and in university teaching in general during these years, the value of history for medical students was appreciated less and less. ${ }^{22}$ Traditional ideals of humanistic learning had come under attack and medicine began to model itself on scientific standards. The clinic and the laboratory replaced the library as medicine's most important research centres. Israëls had been part of a generation that still felt strong ties with the past. In the second half of the nineteenth century, however, these ties were cut. The traditional ideal of the universitas litterarum was undermined, and medicine was no longer the unified discipline it once had been. This seriously threatened the legitimacy of

\footnotetext{
19 For this, see Willem de Blécourt, 'Irreguliere genezers in de stad Groningen in de tweede helft van de negentiende eeuw', Gronings historisch jaarboek, 1994, 1: 126-41.

${ }^{20} \mathrm{~L}$ Ali Cohen, Handboek der openbare gezondheidsregeling en der geneeskundige politie, met het oog op de behoeften en de wetgeving van Nederland, 2 vols, Groningen, Wolters, 1872, esp. vol. 2, pp. 619-25 (on the medical profession).

$21 \mathrm{~J} \mathrm{G}$ de Lint, De herleving van de geschiedenis der geneeskunde, Gorinchem, Noorduyn, 1924 (public lecture); H E Sigerist, Geneeskunde. Een encyclopaedisch overzicht, translated and edited by J G de Lint, Leiden, H E Stenfert Kroese's Uitgeversmaatschappij, 1933. On De Lint, see J B F van Gils, 'In memoriam dr Jan Gerard de Lint',
}

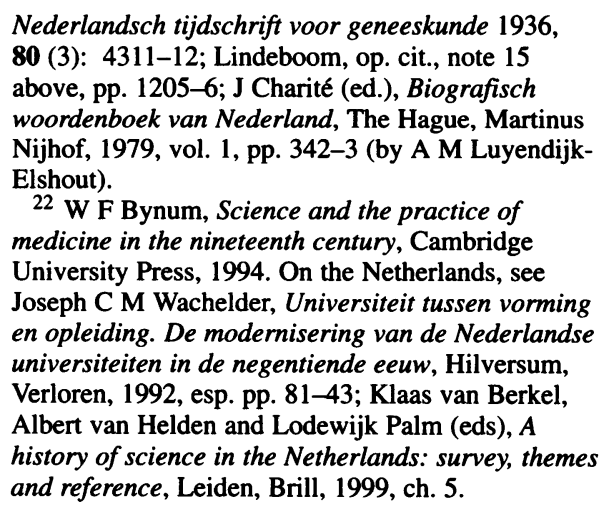




\section{Quackery and Folk Medicine in Dutch Historiography}

medical history. The introduction of scientific methods in medicine led to a break between the present and the past that deprived pragmatic historiography of its ratio. Someone like Claude Bernard, the great French experimental physiologist, once remarked he felt a great distance from the past of medicine. ${ }^{23}$

In 1889 Theodor Puschmann (1844-1899), professor in the history of medicine in Vienna, put forward a plea for medical history that was to have great repercussions. ${ }^{24} \mathrm{He}$ shared Sprengel's views on medical history but, at the same time, was very aware that medicine had changed profoundly. This was, however, no reason to neglect its history. Quite the contrary: the changes made the need for history more compelling than ever. Puschmann wanted to preserve the blessings of modern scientific research without losing sight of the demands of the art of medicine. Anyone who knew the history of his own discipline would never slip into an attitude of easy and superficial materialism. To the history of medicine he assigned three functions: it formed the basis of professional knowledge, it contributed to the refinement of the character of physicians, and it completed general education. Using history, he hoped to maintain unity in medical knowledge and culture at large.

Puschmann's address stirred up a discussion that led to the appointment of professors in medical history throughout western Europe, one of them being Karl Sudhoff in Leipzig. In the same year, 1904, Evert Cornelis van Leersum (1862-1938) was appointed professor in the history of medicine, pharmacology and pharmacognosy at the University of Leiden. ${ }^{25}$ Van Leersum's programme resembled that of Puschmann. In his inaugural address, he observed that medicine had changed profoundly since the middle of the nineteenth century, mainly through the work of Rudolf Virchow, which had dealt the death blow to the classical heritage. Van Leersum wanted to use history as an antidote, as a counterbalance to disintegrating forces within medicine and to materialism and utilitarianism in general. ${ }^{26} \mathrm{He}$ tried to restore the sense of unity in academic medical learning by indicating the historical connections between the growing number of medical sub-disciplines. ${ }^{27}$ In addition to this, he assigned a function to medical history with regard to the doctor-patient relationship. In

${ }^{23}$ Owsei Temkin, 'An essay on the usefulness of medical history for medicine', in idem, The double face of Janus and other essays in the history of medicine, Baltimore, Johns Hopkins University Press, 1977, pp. 68-109, on 79-80.

24 T Puschmann, 'Die Bedeutung der Geschichte für die Medicin und die Naturwissenschaften', Deutsche medicinische Wochenschrift, 1889, 15 (40): 817-20. Puschmann spoke with authority: his Geschichte des medicinischen Unterrichts von den ältesten Zeiten bis zur Gegenwart, Leipzig, Veit, 1889 , was published in the same year.

25 Van Leersum had been the assistant of the physiologist B J Stokvis, who had an excellent reputation as a medical historian. Later on, he became editor of Janus and of the Opuscula selecta Neerlandicorum de arte medica, a series in which important Dutch medical sources were being published and translated. On Van Leersum, see F M $\mathrm{G}$ de Feyfer, 'In memoriam prof. dr E.C. van Leersum', Nederlandsch tijdschrift voor geneeskunde, 1938, 82 (1): 826-8; M A van Andel, 'In memoriam prof. dr E.C. van Leersum', Janus, 1939, 43: 81-3; Lindeboom, op. cit., note 15 above, pp. 1155-6.

${ }^{26}$ For this, see his inaugural address: E C van Leersum, De arts en de geschiedenis zijner wetenschap, Leiden, Brill, 1904. For a retrospective on his professorate, see idem, 'De beoefening der geschiedenis der geneeskunde in Nederland', Nederlandsch tijdschrift voor geneeskunde, 1923, 67 (2B): 1597-602.

27 Although Van Leersum was well aware of the value of physiological experiment for modern medicine, he called on physiologists never to forget the historical roots of their profession, that were "often forgotten or on purpose neglected": E C van Leersum, Old physiological experiments, Leiden, E J Brill, 1913, p. 6 (written on the occasion of the 9th International Congress of Physiologists in Groningen). 


\section{Frank Huisman}

the case of illness, the patient should be able to face the doctor with trust and respect. The latter should not be a mere technician, he should have a refined insight into human character as well. For this, medical history provided the tools: "Only by following the trail that civilization and the human spirit have gone along to reach a higher stage of development is it possible to know and understand one's fellow man". ${ }^{28}$

This conviction led Van Leersum to study the relationship between folk medicine and scientific medicine. Although he was willing to admit folk medicine had discovered some remedies with a demonstrable pharmacological effect, only modern medicine had been capable of converting the raw materials into pure medicines. For this reason, scientific medicine stood on a higher stage than folk medicine. Among his students, Martinus Antonie van Andel (1878-1941) was the most influential. ${ }^{29}$ As a practising physician, Van Andel took a special interest in medical history. In this field, he shared the views of his supervisor Van Leersum. Van Andel too ascribed an integrating function to medical history. He was not only interested in the heroes of science, but in their lesser colleagues and the patient as well. Moreover, he was concerned about the drastic specialization within medicine during his lifetime that threatened to turn the physician into a technician. ${ }^{30}$ In his 'Apologie der historia medica' he wrote: "In these confused times, in which the balance in the social and the scientific field is threatened and in which cold materialism and vague mysticism play a doubtful role, the lessons of history may be of use". ${ }^{31}$ According to Van Andel, the advantage of (compulsory) lessons in medical history at university was that they "contributed to a susceptibility to understanding the way that people thought, which was indispensable for every practising physician". By combining medical history with folk medicine, Van Andel wanted to improve communication between doctor and patient. In order to be able to understand this, we need to know more about his unilinear evolutionary view of human history. ${ }^{32}$

Van Andel stated that in his own time folk belief and science were separated by "strict boundaries". This had not always been the case: in the past, folk medicine and academic medicine had always influenced each other and borrowed from each other. During the nineteenth century, medicine had emancipated itself and become an abstract, experiential science. Due to progress in chemistry and the introduction of experiments on animals, medical research had freed itself from human subjectivity. ${ }^{33}$ Because folk medicine remained unaffected by scientific developments, this had led to an estrangement of

\footnotetext{
28 Van Leersum, op. cit., note 26 above, pp. 31-2.

29 On Van Andel, see F M G de Feyfer, 'In memoriam Martinus Antonie van Andel (1878-1941)', Janus, 1941, 45: 193-5; D Schoute, 'Martinus Antonie van Andel', Handelingen en levensberichten van de Maatschappij der Nederlandsche Letterkunde te Leiden 1941-1942, Leiden, Brill, 1942, pp. 38-45; Charité, op. cit., note 21 above, pp. 12-13 (by A M Luyendijk-Elshout).

${ }^{30} \mathrm{M}$ A van Andel, 'Tweeërlei opvatting over de geschiedenis der geneeskunde', Nederlandsch tijdschrift voor geneeskunde, 1918, 62 (1B): 1520-2; idem, 'Apologie der historia medica', Nederlandsch tijdschrift voor geneeskunde, 1922, 66 (1A): 339-40.

31 Van Andel, 'Apologie', op. cit., note 30 above, p. 340 .
}

32 M A van Andel, Volksgeneeskunst in Nederland, (PhD thesis, University of Leiden, 1909), Utrecht, Van Boekhoeven, 1909; idem, 'Volksgeneeskunst en haar beteekenis voor de Nederlandsche volkskunde', Nederlandsch tijdschrift voor geneeskunde, 1941, 85 (2): 2697-705.

33 Van Andel, op. cit., note 32 above, pp. 85-6. This idea had first been brought forward by J W Gunning in his inaugural address as professor of chemistry and pharmacy in Amsterdam: Een eisch van het natuuronderzoek toegelicht uit de geschiedenis der scheikunde, Utrecht, $\mathrm{C}$ van der Prost, 1865. Gunning argued the change was one from anthropomorphic to abstract scientific reasoning. 


\section{Quackery and Folk Medicine in Dutch Historiography}

physicians from the public. Their relationship could be restored by studying folk medicine from the present and academic medicine from the past, which Van Andel considered as two expressions of the same thing. In his thesis, Volksgeneeskunst in Nederland (Folk medicine in the Netherlands), Van Andel presented modern folk medicine as having its roots in Graeco-Roman medicine. ${ }^{34}$ According to him, folk medicine is not a scientific system, but "a product of intuition, experience, faith, tradition and fantasy". In folk medicine, magico-animistic notions from the beginning of our culture that enable man to cope with fear and anxiety can still be found. Both medical history and folk medicine point at "the unity of feelings towards the dangers of our earthly existence". ${ }^{35}$ For Van Andel, they were part of the universal condition humaine. As such, he considered both disciplines essential for the practising physician. Modern scientific developments threatened to reduce the physician to a materialist technician who could no longer communicate with lay people. Van Andel found a kindred soul in Jan Gerard de Lint, mentioned above. Both were practising physicians in Gorinchem, both were interested in folk medicine, and both had had Van Leersum as their supervisor. ${ }^{36}$ Together they were the pivotal figures in the Dutch medical history of their time. ${ }^{37}$

Nineteen years after Van Andel's thesis, Cornelis Bakker (1863-1933) published a book in the same vein. ${ }^{38}$ Bakker, a practising physician like Van Andel, had been collecting material on folk medicine since 1897. Inspired by the work of well-known medical historians like Sprengel, Haeser, Daremberg, Puschmann, Pagel and Van Leersum, and supported by his colleague Van Andel, Bakker studied folk medicine in his own region. Whereas Van Andel had sent questionnaires to his colleagues asking them to describe the folk customs in their areas, Bakker drew entirely on experience from his own medical practice. After having spent some thirty years on "fieldwork", he published Volksgeneeskunde in Waterland (Folk medicine in Waterland. A comparison with Greek and Roman medicine) in $1928 .{ }^{39}$ By closely reading the classical authors, Bakker claimed to have found abundant evidence for the hypothesis that had set him to work. He argued that much that had always been taken to be the raw empirical material of modern folk mentality was in reality a conglomerate of medicine, philosophy, magic and religion of long-gone centuries. In his introduction Bakker argued that a knowledge of folk mentality

\footnotetext{
34 Van Andel, op. cit., note 32 above. His most important sources were Aristotle, Pliny, Dioscorides, Albertus Magnus and Dodonaeus. This line of thought is also developed in E C van Leersum, 'Over de waardering van oude en volks-geneesmiddelen', Nederlandsch tijdschrift voor geneeskunde, 1914, 58 (1B): 1952-60. On the survival of humoralism in popular thought, see also Vicky Rippere, 'The survival of traditional medicine in lay medical views: an empirical approach to the history of medicine', Med. Hist., 1981, 25: 411-14.

35 Van Andel, op. cit., note 32 above, p. 2705.

36 In 1918 De Lint defended a thesis on Dutch medical popular prints: J G de Lint, 'Geneeskundige volksprenten in de Nederlanden', PhD thesis, University of Leiden, 1918.

37 The Society for the History of Medicine, Mathematics and the Sciences, founded in 1913, regularly held its meetings in Gorinchem: J G van
}

Cittert-Eymers, 'Grepen uit de geschiedenis van het genootschap 1913-1963', in B P M Schulte (ed.), Vijftig jaren beoefening van de geschiedenis der geneeskunde, wiskunde en natuurwetenschappen in Nederland 1913-1963, n.p., 1963, pp. 108-18.

38 On Bakker, see P A de Wilde, 'In memoriam Cornelis Bakker', Nederlandsch tijdschrift voor geneeskunde, 1933, 77 (3): 3915-17; Lindeboom, op. cit., note 15 above, pp. 57-8.

${ }^{39} \mathrm{C}$ Bakker, Volksgeneeskunde in Waterland. Een vergelijkende studie met de geneeskunde der Grieken en Romeinen, Amsterdam, H J Paris, 1928. His most important sources include Hippocrates, Plato, Aristotle, Pliny, Dioscorides, Galen, Theophrastus and Paul of Aegina. More recently, A A Weijnen and A P G M A Ficq-Weijnen, Ziektenamen in de Nederlandse dialacten, The Hague, SDU, 1995, used a similar approach to disease categories in Dutch dialects (see esp. ch. 17). 
made it possible for the physician to get to know the intimate lives of his patients. After his fieldwork, he thought himself better equipped to communicate with them than a colleague who did not have this knowledge. It seems Bakker was aware that the sick man had disappeared from medical cosmology-to use the well-known phrase of Jewson ${ }^{40}$ and that he intended to help his colleagues when he wrote:

I never descend from my high throne to listen with patronizing kindness to the "foolish utterances" of the people, as so often happens, for they would immediately sense this. It would arouse distrust and it would widen the gap that exists between the more and the less educated. This in turn would lead to aversion and it would make the intimate contact that is needed to penetrate into the soul of the people impossible. ${ }^{41}$

Only when the physician has an understanding of the things that move his patients will they be capable of trusting him. This, in turn, is a precondition for communication. Only then can a good diagnosis be made, only then can a therapy be prescribed, and only then can outmoded views be corrected in a gentle way.

In their work, Van Andel and Bakker showed an awareness of and a sensitivity to the complexities of the relationship between patient and healer and between regular and irregular medicine. In their treatment of folk medicine, they used positivism in an ingenious way. By arguing that folk medicine was based on rudiments of Graeco-Roman medicine, popular belief was made both strange and familiar at the same time. It was backward because it lagged behind in development but, on the other hand, it was cast in the highly understandable terms of humoralism. A physician, when not patronizing, could put his knowledge of folk medicine to great therapeutical effect. In short, the second type of medical historian was seeking to reconcile the split between science and the humanities so as to bridge the resultant gap between physician and patient. Being practising physicians, they wanted to restore communication and mutual understanding in the consulting room in a confusing transitional period.

\section{The History of Quackery and the Struggle for the Patient}

There was a second response to the transformation of medicine in the nineteenth century. Unlike Van Andel, De Lint and Bakker, authors of this type did not try to bridge the epistemological split between physicians and laymen, but rather emphasized it. They set themselves up as educators of the people, who possessed expert knowledge. The public was considered incompetent and incapable of correct judgement in medical matters. This applied not only to members of the lower strata of society, but to the rich and the intelligent as well: they all consulted quacks. Writers of this type had two goals: first, they wanted to unmask quacks and expose them to the public in all their nakedness, and second, they wanted to persuade the public to accept scientific medical discourse as superior. They were convinced medical science held a promise for the future and they wanted to win over the public to their belief in progress. It was considered imperative to publicize the potential of science. The public was rebuked for its anthropomorphic way of

\footnotetext{
${ }^{40} \mathrm{~N}$ Jewson, 'The disappearance of the sick man from medical cosmology, 1770-1870', Sociology, 1976, 10: $225-4$.
}

${ }^{41}$ Bakker, op. cit., note 39 above, p. ix. 


\section{Quackery and Folk Medicine in Dutch Historiography}

thinking and its gullibility. This attitude made patients easy victims of quacks with their sophisticated ways of luring the sick into buying worthless remedies.

A typical representative of this type is Gerardus Wijnandus Bruinsma (1840-1914), a practising physician in Steenbergen. ${ }^{42}$ A social liberal, he published in a journal called Vragen des tijds (Questions of the time) on such topics as the education of midwives, the research into foodstuffs in state pharmacies, vital statistics, and medical legislation. ${ }^{43} \mathrm{He}$ was very committed to the solution of important questions in public health and tried to get debates going among his peers by publishing in Vragen des tijds. Also, he was keen to raise the awareness of people through the Society for the Common Benefit (Maatschappij tot Nut van 't Algemeen). ${ }^{44}$ In general, he can be said to have followed a two-track strategy. On the one hand he advocated strict medical legislation and strict judicial persecution of irregulars, while on the other, he was very active in the field of informing the public. ${ }^{45}$ His brother Vitus Jacobus (1850-1916), who was a teacher of chemistry at the grammar-school (gymnasium) of Leeuwarden, can also be characterized as an educator of the people. He wrote schoolbooks explaining the workings of the human body and the principles of hygiene, fulminated against secret remedies and combated alcoholism. ${ }^{46}$ Together, Gerardus and Vitus published their first book against quackery in 1878, called De kwakzalverij met geneesmiddelen en de middelen om haar te bestrijden (Medical quackery and the means to combat it). ${ }^{47}$ In it, they stated that the essence of quackery is making a lot of money by wilful deceit. They pointed to the fact that the cost of the remedies on offer was extremely high, with profits mounting to 2000 per cent, and tried to combat quackery by analysing its selling techniques.

The Bruinsmas explained how quacks cleverly took advantage of popular ideas. In their advertisements quacks often used the idiom of humoralism, which was understood by the public. ${ }^{48}$ The remedies on offer were said to purify the blood, to expel peccant humours and

\footnotetext{
42 On G W Bruinsma, see Lindeboom, op. cit., note 15 above, pp. $286-7$.

43 On this latter topic, he published Geneeskundig wetboek van Nederland, inhoudende wetten, besluiten, reglementen en voorschriften, inzonderheid van belang voor geneeskundigen, apothekers, tandmeesters, vroedvrouwen en veeartsen, benevens hetgeen betrekking heeft op de zorg van den staat voor het leven en de gezondheid der burgerij 2 vols., Tiel, 1879-1883, and Nieuw geneeskundig wetboek. Overzicht en aanwijzing van wetten, besluiten, reglementen enz. die van belang zijn voor geneeskundigen, apothekers enz., Haarlem, De Erven F Bohn, 1898.

${ }^{44}$ His De kwakzalverij met geneesmiddelen. Haar oorsprong, karakter en bestrijding, Amsterdam, Van Looy, 1906, on the struggle against quackery with medicines was published in the educational series of this Society.

45 In 1903, he published a book in which he explained Malthusianism to the general public: $D e$ leer van Malthus, voor Nederland toegelicht, Haarlem, De Erven F Bohn, 1903.

46 Vitus Bruinsma, 'Onze strijd tegen den geheimmiddel-handel in Nederland', De farmaceut,
}

1877, 2 (23); idem, Ons lichaam en onze gezondheid. Leerboekje over de samenstelling en de werking van het menschelijk lichaam, de beginselen der gezondheidsleer en de eerste hulp bij ongelukken, Groningen, Noordhoff, 1900; idem, Wat de alcohol zelf ervan zeide, St. Anna-Parochie, Kuiken, 1904.

47 Vitus Bruinsma and G W Bruinsma, De kwakzalverij met geneesmiddelen en de middelen om haar te bestrijden. Een boek voor allen die hun gezondheid en hun beurs liefhebben, Leeuwarden, Van Belkum, 1878. Two years later, they published De hedendaagsche kwakzalver. Een waarschuwing voor allen die hun gezondheid en hun beurs op prijs stellen, Leeuwarden, $\mathrm{H}$ van Belkum, 1880.

48 Note that the Bruinsma brothers are fully in line here with the arguments of Van Andel and Bakker. On the attractions of humoral thinking for people living in the late nineteenth century, see also Charles E Rosenberg, 'The therapeutic revolution: medicine, meaning and social change in nineteenth-century America', in Morris J Vogel and Charles E Rosenberg (eds), The therapeutic revolution: essays in the social history of American medicine, Philadelphia, University of Pennsylvania Press, 1979, pp. 3-25. 


\section{Frank Huisman}

to strengthen a weak stomach. Laxatives especially were very popular with the public. In a bitter tone, the Bruinsmas commented that the principle of well-known quacks like Thomas Holloway seemed to be "the more defecation, the better". The brothers presented chemical analyses of more than fifty secret remedies. Some of them turned out to be mere foodstuffs, some did not contain any active ingredients at all, and others proved to be downright poisonous. Moreover, many remedies required self-diagnosis by the patient, which the brothers considered unacceptable. At all times the expert opinion of a doctor was needed, in order to prevent damage being done. The Bruinsmas went to great lengths to prove the misleading nature of testimonials of successful treatment. They investigated some 100 German testimonials-many of which proved to be false-and sent the results of their inquiries to 230 newspapers in order to persuade them never to include quack advertisements again. Their indictment ended with suggestions for improving medical legislation and with an appeal to the state for the stricter prosecution of quacks. In 1880, two years after publishing their book, the Bruinsma brothers founded the Dutch Society Against Quackery, with which they fought their campaign on a regular basis. ${ }^{49}$ They published a monthly newsletter, in which they exposed quacks and printed the results of chemical analyses of medicines. ${ }^{50}$ The aim of the Society was fully in line with that of the Society for the Common Benefit, in which they both participated: the enlightenment of the people through the popularization of science.

Medical history did not play a role in the Bruinsmas' arguments, quite the opposite. Unlike many others, they explicitly contrasted the traditional charlatan with the modern quack. ${ }^{51}$ To many people, the screaming market vendor was still the archetype of the quack, and they were therefore not on the alert for the creeping evil of modern quackery, which was extensive, commercial and anonymous. For the Bruinsmas, Holloway was the emblematic modern quack. He was deceitful, his only objective being to make money out of selling his factory products on a large scale. The degree of organization of his company was unprecedented. All over the world he had branches, sales representatives and hawkers. The success of this arch-quack had opened the eyes of many shrewd merchants, especially in America, and incited their entrepreneurial spirit. For that reason, the Bruinsmas focused on contemporary widespread and anonymous quackery by analysing self-help books, letters and advertisements.

Unlike the Bruinsmas, Hendrik Jan Willem Droogleever Fortuyn (1870-1970), who belonged to the same camp, and who was a practising physician and a member of the executive committee of the Royal Dutch Society for the Advancement of Medicine (KNMG) from 1922 to 1937, explicitly used history as a rhetorical instrument to combat quackery. ${ }^{52} \mathrm{He}$ did not use solid historical studies like those of Sprengel, Haeser,

\footnotetext{
${ }^{49} \mathrm{G}$ W Bruinsma, 'Helpers en wegbereiders', in Gedenkboek van de Vereeniging tegen de kwakzalverij 1880-1905, Dordrecht, de Dordrechtse Uitgeversmaatschappij, 1906, pp. 43-61, and Vitus Bruinsma, 'De jaren 1878 tot 1880 , de voorbereiding van de oprichting der Vereenigigng', in ibid., pp. 62-74. On the role of the Society in the Dutch battle against quackery, see Van Vegchel, op. cit., note 5 above.

50 On the occasion of the thirty-fifth birthday of the Society, these analyses were compiled by E J Abrahams (1875-1954) in De kwakzalversmiddelen.
}

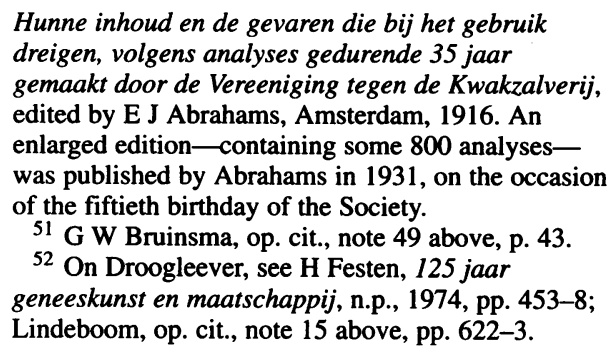

Hunne inhoud en de gevaren die bij het gebruik dreigen, volgens analyses gedurende 35 jaar gemaakt door de Vereeniging tegen de Kwakzalverij, edited by E J Abrahams, Amsterdam, 1916. An enlarged edition-containing some 800 analyseswas published by Abrahams in 1931, on the occasion of the fiftieth birthday of the Society.

${ }^{51} \mathrm{G}$ W Bruinsma, op. cit., note 49 above, p. 43.

52 On Droogleever, see H Festen, 125 jaar geneeskunst en maatschappij, n.p., 1974, pp. 453-8; Lindeboom, op. cit., note 15 above, pp. 622-3. 


\section{Quackery and Folk Medicine in Dutch Historiography}

Daremberg or Puschmann, but founded his views on surveys of a heroic nature. ${ }^{53}$ In his book, called Kwakzalverij, bijgeloof en geneeskunst (Quackery, superstition and medicine), first published in 1940, Droogleever Fortuyn expounded his views on the course of history. ${ }^{54} \mathrm{He}$ said that an evolution had taken place that ran from folk belief (based on good-natured empirical experience) via quackery (conscious deceit) to medicine (synonymous with true knowledge). The first two stages he associated with subjectivity, hope, lay knowledge and stagnation, the latter with objectivity, rationality, expertise, progress and humanity. Droogleever Fortuyn followed in the tradition of the Bruinsmas, whom he praised as pioneers and unselfish fighters who had devoted much time and energy to combating quackery. Like them, he showed that modern patients lacked an adequate understanding of academic medicine; like them, he attached great importance to informing the lay public, and like them, he advocated stricter legislation and legal prosecution. After having investigated magnetism, terrestrial beams, somnambulism, astrology, faith healing, exorcism, uroscopy, osteopathy, chiropractic and iridiagnosis, Droogleever Fortuyn concluded that quackery and superstition were not rooted in solid science. He stated that irregular healers, exactly like their patients, only paid attention to their clients' complaints but remained in the dark about the real pathogens. Superstition was based on fear combined with hope. It occurred when man felt helpless in the face of threatening forces and it could be made to disappear through science.

Using the history of medicine-the "long and hard struggle with the secrets of life" 55 Droogleever Fortuyn drew lines of demarcation between regular and irregular medical practitioners, each with their own tradition. For medicine, it had been a long and difficult quest for the truth, that had led from the Greek Pantheon via Hippocrates and Galen, and via Vesalius, Paré and Harvey to nineteenth- and twentieth-century heroes like Jenner, Auenbrugger, Laënnec, Semmelweis, Lister, Virchow, Pasteur, Röntgen, Ehrlich and Von Behring. The growth in scientific knowledge was accompanied by a growth in humanity (with Pinel and Nightingale being his champions). Combined, they stood for "victory over pernicious quackery, over the distasteful remedies of folk medicine, over ignorance and incompetence". ${ }^{56}$ According to Droogleever Fortuyn, information on modern medicine, characterized by science, humanity and therapeutical success, was the key to enlightening the public. Therefore, information on the nature and power of medicine should be made available in schools, libraries and waiting rooms, and through newspapers, the cinema, the theatre, the radio, and the publication of brochures and booklets.

In the thirties, another group of physicians was active that can be situated somewhere between Van Andel and Bakker on the one hand and the Bruinsma brothers and Droogleever Fortuyn on the other. ${ }^{57}$ Towards the end of the twenties, the Amsterdam

\footnotetext{
${ }^{53}$ His sources include C Reissig, Medizinische Wissenschaft und Kurpfuscherei. Zur Aufklärung des Publikums gemeinverständlich, Leipzig, Vogel, 1900; Paul de Kruif, Microbe hunters, New York, Harcourt, Brace, c. 1926; idem, The fight for life, New York, Harcourt, Brace, c. 1938; Howard W Haggard, Mystery, magic and medicine. The rise of medicine from superstition to science, New York, Doubleday, Doran, 1933, and the Dutch translation (1939) of Andrea Majocchi's La vita di chirurgo.

${ }^{54} \mathrm{H}$ J W Droogleever Fortuyn, Kwakzalverij,
}

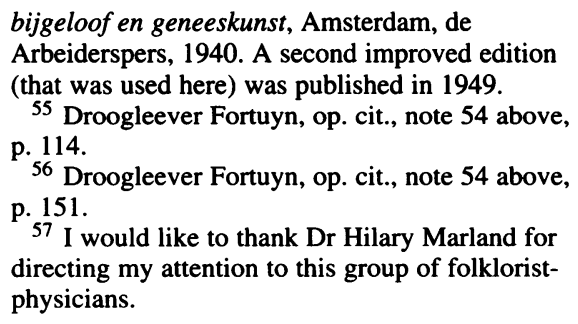

57 I would like to thank Dr Hilary Marland for directing my attention to this group of folkloristphysicians. 


\section{Frank Huisman}

professor of obstetrics, A H M J van Rooy, took up the plan to use medical folklore and medical history to chart obstetric provisions in the Netherlands. In the thirties, Van Rooy's programme materialized in four theses supervised by him. ${ }^{58}$ The authors were all familiar with the work of Van Leersum, Van Andel and Bakker and even used their research methods (i.e., sending out questionnaires and making personal observations), which they supplemented with statistical data on infant and child mortality. In their attitude towards folk practice, however, they came closer to the work of the Bruinsmas and Droogleever Fortuyn. The knowledge they obtained on folk medicine was to be mobilized in the battle against the "survivals" and the "prelogical mentality" of the common people. 59 Thus, these theses mainly served to illustrate the benefits of modern medicine and to bemoan the survival of the folk tradition, which was considered a threat to public health. After having fathomed the soul of the people, they tried to persuade them to use modern therapies. In the end, their ambition was to involve the entire population in health care by including them in the network of obstetricians, physicians, midwives and home nursing services (kruisverenigingen).

\section{Whose History? Coming to Terms with Different Narratives}

From the above it becomes clear that among physicians there have been at least three approaches to folk medicine and quackery, ranging between disinterest, sympathy and antipathy. What united them, however, was their evolutionary perspective on medicine. Post-war Dutch historiography by physicians did not produce any new approaches to folk medicine and quackery. Later publications by physicians had the same point of departure. Thus, Gerrit Arie Lindeboom (1905-1986) wrote a new handbook on the history of medicine, Paul van Dijk wrote on folk medicine, and Leonardus Franciscus Bakker and Cees Renckens on quackery. ${ }^{60}$ Like their predecessors, contemporary physician-historians start from two assumptions: first, that the contents and boundaries of orthodox medicine are clear, and, second, that folk medicine and quackery can be defined as whatever is contrary to orthodoxy.

Renewal came from non-physicians. ${ }^{61}$ In the 1970 s and 1980 s a radical change took place within general history that was to have great repercussions for medical history as well. Many new sub-disciplines came into being, medical history being one of them. "New" medical history was less interested in developments in medical science than in the

$58 \mathrm{~J}$ H Starmans, Verloskunde en kindersterfte in Limburg. Folklore, geschiedenis, heden, Maastricht, Van Aelst, 1930; P E G van der Heijden, De zorg voor moeder en kind in Noord-Brabant, n.p., [1934]; A C Drogendijk, De verloskundige voorziening in Dordrecht van c. 1500 tot heden, Amsterdam, Paris, 1935; J H Hagenbeek, Het moederschap in Overijssel. Een onderzoek naar de verloskundige voorziening en de zuigelingenzorg in de provincie Overijssel, Zwolle, Tulp, 1936.

59 Hagenbeek, op. cit., note 58 above, p. 140; Starmans, op. cit., note 58 above, p. 419.

60 G A Lindeboom, Inleiding tot de geschiedenis der geneeskunde, Haarlem, Bohn, 1961 (in 1993, the seventh edition of this book was published); Paul van
Dijk, Volksgeneeskunst in Nederland en Vlaanderen, Deventer, Ankh-Hermes, 1981; Leonardus Franciscus Bakker, Kwakzalverij en onbevoegd uitoefenen der geneeskunst, Assen, Van Gorcum \& Comp., 1969; Cees Renckens, Hedendaagse kwakzalverij. Alternatieve geneeswijzen nader beschouwd, Amsterdam, Prometheus, 1992. Renckens has been chairman of the Dutch Society Against Quackery since 1988.

61 The impulse that was given by physicians like Henry Sigerist, Owsei Temkin, Ludwig Edelstein and Erwin Ackerknecht and also by historians like Richard Harrison Shryock and Charles Rosenberg has largely by-passed the Netherlands. 


\section{Quackery and Folk Medicine in Dutch Historiography}

ways in which social relationships found an expression in illness, health and healing and in the organization of health care systems. At the same time, the counter-culture of the 1960s had bred an anti-science sentiment. At a time of a growing environmental awareness and of uneasiness about technology, the value of science for mankind was brought into debate. This critical attitude led to a revaluation of the history of science that had helped to create the positive image of science. ${ }^{62}$ Because unconditional belief in science was wavering, eyes were opened to the role the older medical history had played in legitimating the monopoly of physicians in the medical market. ${ }^{63}$

Historians, sociologists and anthropologists entered the field, looking at the history of illness, pain and healing from a non-medical perspective. Broadly speaking, they argued that (historical) reality is contingent and that medical history had merely stylized the past in order to serve contemporary needs and interests. ${ }^{64}$ New medical history did not take orthodox medicine as a frame of reference. Instead, it studied the whole spectrum of ideas, notions and practices with regard to health and illness, borrowing its methods from the sociology of knowledge and (medical) anthropology. Anthropology had made it clear that healing practices are always culture bound. They originate in daily life, are tested and modified, and develop into cultural codes that help to make sense of illness, and to guide illness and consultation behaviour. Biological determinism and ontological illness concepts were abandoned, while the intellectual and social status of healers was considered to be the outcome of the interaction between social, political and economic forces and of "negotiations" between the parties involved. ${ }^{65}$

Because the contents and boundaries of medicine were not considered to be clear-cut, the approach to "folk medicine" and "quackery" was subject to change as well. The new attitude exposed the blind spots of conventional medical history. When society instead of medicine was taken as a frame of reference, it became clear that "alternative medicine" did not represent the dark side of medicine, but rather shed light on a whole spectrum of social, "non-medical" topics. It was found that theories on illness and healing could be expressions of political protest, religious fervour or simply a lifestyle. ${ }^{66}$ It became clear that it is difficult to generalize about alternative medicine in the way that traditional historiography did. When the above-mentioned Dutch historians are looked at again, the explicit labelling activity of Van Andel attracts attention. He distinguished between orthodox medicine, popular medicine, folk medicine and quackery. ${ }^{67}$ Popular medicine he defined as popularized orthodox medicine. It referred to advice given by academic physicians to the public through leaflets, brochures and public lectures. He considered folk medicine to be an autonomous ensemble of ideas and practices that was supported by the people. He presented it as an integrated system that enabled laymen to act on their own initiative in the event of illness, without external medical advice. Folk medicine differed

\footnotetext{
62 It is ironic to note that many representatives of the critical or anti-heroic tradition in medical history share their evolutionary perspective with members of the heroic tradition: Dorothy Porter, 'Introduction', in idem (ed.), The history of public health and the modern state, Amsterdam, Rodopi, 1994, pp. 1-44.

63 Van Vegchel, op. cit., note 9 above.

${ }^{64} \mathrm{See}$, for example, Loren Graham, Wolf Lepenies and Peter Weingart (eds), Functions and uses of
}

disciplinary histories, Dordrecht, Reidel, 1983.

65 Rosenberg, 'Framing disease: illness, society and history', in Rosenberg and Golden, op. cit., note 1 above, pp. xiii-xxvi.

66 Roger Cooter (ed.), Studies in the history of alternative medicine, Houndmills, Macmillan Press, 1988.

67 Van Andel, op. cit., note 32 above, pp. 4-8. 


\section{Frank Huisman}

from popular medicine in that it used obsolete remedies. It was thought to be empirical and experience-based, whereas academic medicine was considered to be rational and consistent. On the whole, however, folk medical advice was given in good faith. This could not be said of quackery, which was presented as conscious and wilful fraud by Van Andel, its essence being financial gain not humanitarianism. The difference between folk medicine and quackery was that folk medicine was unselfish, whereas quackery was essentially commercial. ${ }^{68}$

In this context, it is interesting to look again at Van Andel's remark, "the folk remedies of today are the scientific ones of yesterday". 69 The anthropologist Willem de Blécourt, who has done much research on irregular healers in the Netherlands, has pointed out that the boundaries Van Andel has constructed between folk medicine and quackery have less to do with their actual content than with medical politics. ${ }^{70}$ By implication, the same applies to the distinction between regular and irregular healers. ${ }^{71}$ Some irregulars were rendered harmless by the use of the label "folk healer", which projected them back to an innocent "world we have lost". Van Andel's comment on folk remedies makes them familiar and puts them at a distance (in development) while, at the same time, rendering them harmless. Therefore, De Blécourt looks at the historiography of Van Andel and Bakker as an accompanying phenomenon of medical professionalization. Something similar can be said about the Bruinsma brothers and Droogleever Fortuyn. From the difficulty they had in making sense of quackery and in understanding why the public ignored their information and persisted in consulting quacks, we can conclude that their outlook on both medicine and history was too simplistic. Their frustrations seem to have originated in the paradox of positivism: on the one hand, modern science was claimed to be superior, while, on the other, not everyone seemed to be convinced of this. ${ }^{72}$ Moreover, not all irregulars were as highly organized as Holloway. In fact many of them did not actively confront or defy orthodox medicine or try to swindle the public, but simply tried to make a handful of sous by organizing a somnambulistic seance, by fortune telling, or by treating patients in some other way. Their healing activities very often stemmed from their poor social condition. ${ }^{73}$

The change of course that medical history has taken in the last few decades has demolished the historic image of the heroic battle of medicine against suffering and disease without putting a consistent image in its place. It has been argued that medical

68 A similar line of thought is developed by Hector Treub in 'Over "kwakzalverij", in Gedenkboek, op. cit., note 49 above, pp. 1-42.

69 Van Andel, op. cit., note 32 above, p. 16.

70 Willem de Blécourt, 'Het Staphorster boertje. De geneeskundige praktijk van Peter Stegeman (1840-1922)', in Marijke Gijswijt-Hofstra (ed.), Geloven in genezen. Bijdragen tot de sociaalculturele geschiedenis van de geneeskunde in Nederland. Special edition of Volkskundig Bulletin, 1991, 17: 171-94, on pp. 185-7. Cf. 'The fringe/orthodoxy dichotomy can, of course, usefully contribute to an understanding of the historical sociology of the medical profession': Cooter, op. cit., note 66 above, p. xii.
${ }^{71}$ On a similar false dichotomy (between elite culture and popular culture), see Willem Frijhoff, 'Inleiding: historische antropologie', in Peter te Boekhorst, Peter Burke and Willem Frijhoff (eds), Cultuur en maatschappij in Nederland 1500-1850, Meppel, Boom, 1992, pp. 11-38, esp. pp. 25-31.

72 For a new perspective on therapeutic efficacy, see Rosenberg, op. cit., note 48 above; John Harley Warner, The therapeutic perspective: medical practice, knowledge and identity in America 1820-1885, Cambridge, Mass., Harvard University Press, 1986.

73 Willem de Blécourt, Het amazonenleger. Irreguliere genezeressen in Nederland, $\mathrm{ca}$. 1850-1930. Amsterdam University Press (forthcoming). 
history no longer has a story to offer, but only approaches. ${ }^{74}$ Some people regret this situation, in which incommensurable narratives seem to exist side by side, while others react with outright hostility, physicians and non-physicians denouncing each others' methods and narratives. ${ }^{75}$ However, it seems to me that historical pluralism should not be suppressed but, rather, welcomed and adjusted to the subject's advantage. The difference in narrative sheds light on presentist preoccupations, the agenda determining the contents of the story as well as the identity of the "implicit reader". Whereas Ali Cohen and Israëls were teachers addressing themselves to their students, Van Andel and Bakker wanted to get an exchange of ideas going among practising physicians on the doctor-patient relationship. The Bruinsmas and Droogleever Fortuyn sought to mobilize support for stricter medical legislation while, last but not least, historians and anthropologists have elaborated on a whole range of social topics from the perspective of illness and healing. In the process, they have made us aware of the constructed nature of both medical and historical knowledge. Historiography can never hope to present the ultimate truth; in this sense, the discipline has lost its innocence for good. However, by comparing the style and content of the different narratives about the past with the social interests, disciplinary backgrounds and political agendas of their authors, it can make an important contribution to our understanding of medicine and its place in society.

74 Cooter, op. cit., note 66 above, pp. $x-x x$.

75 For this "clash of cultures" see, for example, 'Medical history without medicine. Editorial', J. Hist. Med. allied Sci., 1980, 35: pp. 5-7; Linda
Bryder and Richard Smith, 'Editorial introduction', Soc. Hist. Med., 1988, 1: v-vii; M Norton Wise, 'The enemy without and the enemy within', Isis, 1996, 87: 323-7. 